\title{
INTEGRATED FRUIT PRODUCTION (IFP) FOR NEW ZEALAND PIPFRUIT: EVALUATION OF DISEASE MANAGEMENT IN A PILOT PROGRAMME
}

\author{
D.W.L. MANKTELOW ${ }^{1}$, R.M. BERESFORD ${ }^{2}$, A.J. HODSON ${ }^{3}$, \\ J.T.S. WALKER ${ }^{1}$, T.A. BATCHELOR ${ }^{4}$, H.E. STIEFEL ${ }^{5}$ \\ and I. HORNER ${ }^{1}$
}

\author{
HortResearch, ${ }^{1}$ Hawke's Bay Research Centre, Pvt. Bag 1401, Havelock North \\ ${ }^{2}$ Mt. Albert Research Centre, Pvt. Bag 92169, Auckland \\ ${ }^{3}$ Taylor, Pinchin and Associates Ltd., PO Box 56, Hastings \\ ${ }^{4}$ ENZAFRUIT New Zealand (Int.), PO Box 1101, Hastings \\ ${ }^{5}$ Agriculture New Zealand, Pvt. Bag 9024, Hastings
}

\begin{abstract}
In 1996-97, 88 orchards were involved in a national pilot New Zealand Integrated Fruit Production(IFP) programme for pipfruit. Disease management under this programme focused on black spot (Venturia inaequalis) and powdery mildew (Podosphaera leucotricha). Recommended fungicide use in the IFP programme was based on monitoring black spot infection periods, ascospore counts and black spot and powdery mildew disease incidence. The disease management programme is described in this paper, together with data on fungicide use and disease control. Results from the pilot IFP programme were generally favourable and findings are discussed in relation to wider adoption of IFP by the New Zealand pipfruit industry.
\end{abstract}

Keywords: Integrated Fruit Production, IFP, disease management, fungicide use, apple

\section{INTRODUCTION}

The New Zealand Integrated Fruit Production for pipfruit(NZIFP-P), was introduced in the 1996-97 season in a pilot programme involving 88 apple orchards in the principal fruit growing regions. The basic tenets and purpose of the programme are described by Batchelor et al. (1997). The section of the NZ IFP-P manual (Anon. 1996) on diseases was developed to describe control principles and acceptable practices for management of black spot (Venturia inaequalis), powdery mildew (Podosphaera leucotricha), crown and collar rots (Phytophthora cactorum) and fire blight (Erwinia amylovora).

The NZ IFP-P guidelines on fungicide use were developed from European IFP standards (Anon. 1994), which have two key restrictions: limits to postharvest fungicide use in order to minimise fruit residues; and use of no more than three applications per season of dithiocarbamate (EDBC) fungicides, in order to avoid disruption of integrated mite control. Examination of New Zealand disease management practices suggested that relatively little change was needed to meet the European IFP standards. Posthavest fungicides have not been permitted by ENZAFRUIT, who set quality standards for all apples exported from New Zealand, so New Zealand growers already exceeded the European IFP standards in that respect. A maximum of three applications per season of the EBDC fungicides metiram and mancozeb was set as a target for NZ IFP-P in the 1996-97 season. Restrictions on ziram use were not included, as this EBDC is not considered disruptive to predatory mites (Wearing pers. comm.). Fungicide resistance management, which was not addressed in the European standards, was included in the New Zealand manual. Growers were expected to adhere to published fungicide resistance management strategies (Bourdot and Suckling 1996) which recommend maximum seasonal use of no more than four applications of DMIs (demethylation inhibitors, Table 
3), six of dodine and two of streptomycin. In addition, growers were advised not to apply products at rates greater than those recommended on the label.

NZ IFP-P disease management recommendations integrated control measures for several diseases into a disease management system (Manktelow and Tate 1991). Use of fungicides, or any other management practice, was acceptable, provided it could be justified in terms of sustainable crop production, and met safety and marketing requirements.

This paper describes the management practices for black spot and powdery mildew control which were employed in the 1996-97 pilot programme, and compares fungicide use and disease levels under IFP with those under conventional production. Possible modifications to disease management under IFP in future seasons are also discussed.

\section{METHODS}

Growers from 88 orchards voluntarily entered areas of at least 2 ha into the pilot programme. These growers were provided with manuals and underwent two training sessions. The first session introduced growers to the manual and the principles of IFP, while the second included practical training in disease identification and sampling. Participating growers had access to additional advice and support through IFP discussion groups (Batchelor et al. 1997).

The strategy for black spot and powdery mildew control promoted in the manual was to prevent primary spring infections through a combination of protectant and curative fungicide use. Growers were advised to apply black spot fungicides over the peak ascospore release period, which was identified as a period 10 days either side of the main apple bloom period. For black spot it was also recommended that growers use data on monitored infection periods and ascospore release to aid decisions on use of curative fungicides.

Growers or their consultants were expected to sample for black spot and powdery mildew in November or December. The disease levels identified at that time provided an indication of the likely use of fungicide required for the rest of the season. Blocks with low disease levels $(<0.1 \%$ incidence of black spot on leaves or fruit and $<1 \%$ powdery mildew incidence on shoots) were considered at low risk of further increase in these diseases, allowing fungicide use to be substantially reduced in the latter part of the season.

Consultants undertook a black spot assessment at harvest to provide data for programme evaluation. This followed the protocol established for the November/ December sample, whereby 100 fruit and all leaves on five expansion shoots were assessed for black spot on each of 10 trees per variety block ( $c a .1$ ha). Powdery mildew was assessed as the incidence on extension shoots, with 10 shoots assessed from each of 10 trees per variety block. Data were collected from up to four varieties per property and approximately 300 cultivar blocks were examined nationally. Data from 146 Hawkes Bay IFP blocks (59 growers) are reported in this paper. Disease was also assessed on 20 reference apple blocks (from 9 IFP growers), where management followed conventional fruit production (CFP) methods.

All export apple growers must complete a Pest Control Record Book (PCRB) giving details of pesticide use. These records allowed analysis of fungicide use and grower compliance with IFP recommendations. All records were screened for completeness and any blocks with records of fewer than seven black spot fungicide products applied were excluded from the analysis (this was considered the minimum requirement to ensure commercially acceptable black spot control on the cultivars examined, implying that PCRBs with fewer records were incomplete for some reason). The analysis used approximately equal numbers of blocks from early (Gala strains, Cox and Fiesta) and late (Braeburn strains, Fuji and Granny Smith) season cultivar groups. PCRB data from all Hawkes Bay and Central Otago orchards were compared to examine the relationship between EBDC fungicide and miticide use.

\section{RESULTS AND DISCUSSION}

Black spot and powdery mildew incidence at harvest were comparable in the IFP and CFP blocks (Table 1). Black spot incidence in Hawke's Bay in the 1996-97 season was unacceptably high on many orchards, as many growers failed to apply fungicides in 
response to unusual infection conditions experienced in late September which were coincident with high ascospore numbers (Beresford and Manktelow 1996). Detailed examination of 20 PCRBs from blocks with over $2 \%$ black spot on fruit showed that in 15 cases no fungicides were applied in the 27 day interval between 13 September and 10 October. This failure of the black spot control programme on some orchards could not be attributed directly to the IFP programme. Many growers appeared not to understand the black spot management strategy under IFP, which was to prevent primary infection and then, given low disease levels, to reduce black spot fungicide use closer to harvest. The importance of preventing primary infection will be addressed in future education for IFP growers.

TABLE 1: Harvest black spot and powdery mildew levels on Hawke's Bay integrated fruit production (IFP) and conventional fruit production (CFP) blocks ${ }^{1}$.

\begin{tabular}{lcccc}
\hline & \multicolumn{5}{c}{ Blocks with levels in range } \\
& $<0.1 \%$ & $0.1-1.0 \%$ & $1.0-2.0 \%$ & $>2 \%$ \\
\hline Black spot on fruit & & & & \\
IFP & 41.8 & 39.0 & 8.2 & 11.0 \\
CFP & 58.8 & 29.4 & 0 & 11.8 \\
Black spot on leaves & 74.0 & 19.2 & 3.4 & 3.4 \\
IFP & 70.6 & 17.6 & 5.9 & 5.9 \\
CFP & $1 \%$ & $1-5 \%$ & $>5 \%$ & \\
& $<1 \%$ & & & \\
Powdery mildew on shoots & 3 & 7 & 80 & \\
IFP & 0 & 5 & 90 & \\
CFP &
\end{tabular}

${ }^{1}$ Data were drawn from 146 IFP and 20 CFP blocks

Powdery mildew was assessed as the incidence of shoots affected by this disease. However disease severity (percentage leaf area affected) associated with high incidence of diseased shoots varied greatly, and the shoot incidence assessment appeared not to accurately reflect powdery mildew damage at high shoot incidence (Manktelow and Beresford unpubl. data). Guidelines for powdery mildew sampling and management will be reviewed for the 1997-98 manual, and will probably involve assessing powdery mildew on individual leaves, as occurs for black spot. The early season sample for powdery mildew may also be made earlier than December so that more fungicide options are available in response to monitored disease levels.

Analysis of grower PCRBs provided a measure of how well fungicide use recommendations in the IFP programme were followed. Comparison of PCRBs from IFP blocks with those from CFP blocks indicated that IFP blocks tended to use fewer metiram or mancozeb applications. A greater proportion of IFP than CFP blocks in each region complied with DMI fungicide resistance management use restrictions (Table 2). The situation for dodine was similar, except that in Hawke's Bay, fewer IFP than CFP blocks used six or fewer applications.

Restrictions on fungicide use in the 1996-97 season IFP programme were only recommendations, and are likely to remain so. The only mandatory pesticide use requirements specific to IFP will be a limit on the maximum number of pesticide use points accrued from all agrichemical use (Walker et al. 1997). The relatively low points assigned to fungicides makes it unlikely that this aspect will constrain fungicide use. Fungicide use has been observed to vary considerably between growers (Manktelow et al. 1995) and typically large variations were observed from the 1996-97 data (Table 3). It is anticipated that targeted education of high agrichemical users will bring about a 
gradual reduction in agrichemical use, driven by associated cost savings.

TABLE 2: Regional analysis of CFP and IFP blocks meeting IFP fungicide use recommendations in Hawkes Bay $(\mathrm{HB})$, Nelson $(\mathrm{N})$ and Central Otago (O).

\begin{tabular}{|c|c|c|c|c|c|c|c|}
\hline \multirow[t]{2}{*}{ Fungicides } & \multirow{2}{*}{$\begin{array}{l}\text { Max. use } \\
\text { targeted } \\
\text { under IFP }\end{array}$} & \multicolumn{3}{|c|}{$\begin{array}{l}\text { IFP blocks within } \\
\text { use target }(\%)\end{array}$} & \multicolumn{3}{|c|}{$\begin{array}{l}\text { CFP blocks within } \\
\text { use target }(\%)\end{array}$} \\
\hline & & HB & $\mathrm{N}$ & $\mathrm{O}$ & $\mathrm{HB}$ & $\mathrm{N}$ & $\mathrm{O}$ \\
\hline $\mathrm{EBDC}^{1}$ & $\begin{array}{c}3 \\
(5)^{2}\end{array}$ & $\begin{array}{l}42 \\
65 \\
\end{array}$ & $\begin{array}{l}56 \\
64 \\
\end{array}$ & $\begin{array}{l}42 \\
66 \\
\end{array}$ & $\begin{array}{l}14 \\
29 \\
\end{array}$ & $\begin{array}{l}26 \\
37 \\
\end{array}$ & $\begin{array}{r}6 \\
13 \\
\end{array}$ \\
\hline $\mathrm{DMIs}^{3}$ & $\begin{array}{c}4 \\
(6)^{4}\end{array}$ & $\begin{array}{c}91 \\
100\end{array}$ & $\begin{array}{l}75 \\
90\end{array}$ & $\begin{array}{l}66 \\
68\end{array}$ & $\begin{array}{l}83 \\
87\end{array}$ & $\begin{array}{l}50 \\
81\end{array}$ & $\begin{array}{l}58 \\
80\end{array}$ \\
\hline dodine & 6 & 62 & 88 & 87 & 70 & 75 & 72 \\
\hline No. of blocks & & 262 & 48 & 48 & 3718 & 1142 & 525 \\
\hline
\end{tabular}

${ }^{1}$ metiram and mancozeb. Restrictions relate to maintenance of integrated mite control

${ }^{2}$ Proposed change

${ }^{3}$ cyproconazole, fenarimol, flusilazol, myclobutinal, penconazole, triforine, triadimefon

${ }^{4}$ Maximum allowed previously

TABLE 3: Numbers and range of fungicide products applied on Hawke's Bay IFP $(n=262)$ and CFP $(n=3718)$ orchards.

\begin{tabular}{lrccrrr}
\hline Fungicides & Mean & $\begin{array}{c}\text { IFP } \\
\text { Lower } \\
\text { quartile }\end{array}$ & $\begin{array}{c}\text { Upper } \\
\text { quartile }\end{array}$ & Mean & $\begin{array}{c}\text { CFP } \\
\text { Lower } \\
\text { quartile }\end{array}$ & $\begin{array}{r}\text { Upper } \\
\text { quartile }\end{array}$ \\
\hline EBDCs $^{1}$ & 4.8 & 2 & 6 & 8.0 & 5 & 11 \\
DMIs $_{\text {Dodine }}$ & 2.8 & 2 & 4 & 2.9 & 2 & 4 \\
Black spot fungicides $^{2}$ & 18.8 & 4 & 7 & 5.3 & 3 & 7 \\
\hline
\end{tabular}

${ }^{1}$ metiram and mancozeb

${ }^{2}$ DMIs (Table 2) excluding triadimefon; plus captan, dodine, dithianon, keroxysimmethyl, mancozeb, metiram, pyrimethanil, thiram, ziram

EBDC fungicides have been shown to disrupt integrated mite control programmes based on the predatory miteTyphlodromus pyri. Walkeret al. (1989) reported significant and increasing disruption to mite control once spring use of metiram and mancozeb exceeded four applications. Analysis of the 1996-97 PCRBs yielded a relationship between metiram and mancozeb use and miticide use on the same blocks in Hawke's Bay and Central Otago (Table 4). Few growers who used five or fewer metiram or mancozeb fungicides applied miticides (10\% in Hawkes Bay and $31 \%$ in Central Otago). Miticide use increased with increasing use of metiram or mancozeb in both districts (Table 4). Otago growers generally used more miticides, with $59 \%$ of all blocks treated compared with $16 \%$ of blocks in Hawkes Bay. These data suggest that the present IFP target of no more than three EBDC fungicides may be more restrictive than required to achieve acceptable IMC. A target of no more than five metiram or mancozeb applications has therefore been proposed for the 199798 season.

TABLE 4: Metiram and mancozeb use on apple blocks in Hawke's Bay and Otago, with corresponding miticide use.

Region Metiram + Growers using Blocks in four categories Number 


\begin{tabular}{lccccccc} 
& $\begin{array}{c}\text { mancozeb } \\
\text { applications }\end{array}$ & $\begin{array}{c}\text { miticides } \\
(\%)\end{array}$ & 0 & 1 & 2 & 3 & of miticide use (\%) \\
& \multicolumn{1}{c}{ blocks } \\
\hline Hawkes & $<5$ & 10 & 89.6 & 10.0 & 0.2 & 0 & 1701 \\
Bay & $5-10$ & 16 & $\mathbf{8 5 . 2}$ & 14.1 & 0.7 & 0 & 2104 \\
& $>10$ & 25 & 76.9 & 21.4 & 1.8 & 0 & 1236 \\
Otago & $<5$ & 31 & 68.6 & 22.9 & 8.6 & 0 & 140 \\
& $5-10$ & 58 & 41.8 & 43.5 & 14.5 & 0.3 & 352 \\
& $>10$ & 71 & 28.5 & 53.4 & 8.9 & 9.2 & 305 \\
\hline
\end{tabular}

As fungicide use patterns for black spot and powdery mildew change under IFP, other diseases may assume greater importance. Summer rots, including Glomerella, Botryosphaeria and Botrytis, might emerge as disease problems in some districts if fungicide use is reduced between December and harvest under IFP. Future versions of the IFP manual should address the control of these diseases.

\section{CONCLUSION}

Disease management practices under NZ IFP-P standards require only minor modifications in order to meet, and in some cases exceed, the equivalent European standards. However, the current European recommendation for use of no more than three EBDC fungicide applications per season could possibly be increased under New Zealand conditions without affecting IMC. Adoption of NZ IFP-P standards for disease management is not expected to compromise disease control nor increase the risk of fungicide resistance. Feedback on industry fungicide use through the IFP programme is expected to help achieve fungicide use reductions by current high users.

\section{ACKNOWLEDGEMENTS}

The authors thank Vincent Bus, Chin Gouk and Nicola Park for contributions to the 1996-97 IFP diseases manual and all the growers and consultants who participated in the pilot programme.

\section{REFERENCES}

Anon., 1994. Guidelines for integrated production of pome fruits in Europe. IOBC Technical Guideline III. Second edition. 16pp.

Anon., 1996. New Zealand Integrated Fruit Production - Pipfruit. ENZA New Zealand (International) Ltd. Wellington, N.Z. 137pp.

Beresford, R. and Manktelow, D., 1996. Assessing apple black spot infection risk from monitored weather data. The Orchardist: Dec.:17-20.

Batchelor, T.A., Walker, J.T.S. and Manktelow, D.W.L., 1997. New Zealand Integrated Fruit Production - pipfruit: charting a new course. Proc. 50th N.Z. Weed and Pest Control Conf: (this volume).

Bourdot, G.W. and Suckling, D.M., 1996. Pesticide Resistance: Prevention and Management. N.Z. Plant Protection Society Inc. 225pp.

Manktelow, D.W.L. and Tate, K.G.T., 1991. Development of disease management systems (DMS) for Hawke's Bay pip and stone fruit production. Proc. 44th N.Z. Weed and Pest Control Conf: 216-219.

Manktelow, D.W.L., Beresford, R.M., Batchelor, T.A. and Walker, J.T.S., 1995. Use patterns and economics of fungicides for disease control in New Zealand apples. Intern. Conf. Integrated Fruit Prod. Acta Hort. 442: 187-192.

Walker, J.T.S., Hodson, A.J., Batchelor, T.A., Manktelow, D.W. and Tomkins, A.R., 1997. A pesticide rating system for monitoring agrichemical inputs in New Zealand horticulture. Proc. 50th N.Z. Weed and Pest Control Conf: (this volume).

Walker, J.T.S., Wearing, C.H., Shaw, P.W., Charles, J.G. and Hayes, A.J., 1989. Investigating the effects of protectant fungicides on integrated mite control. II 
Results of three field experiments. Proc. 42 nd N.Z. Weed and Pest Control Conf. $152-158$. 